\title{
PSEUDOTACHYLITE IN THE AGTO AREA
}

\section{Vagn Jensen}

During field work in high-metamorphic complexes of the Agto area glassy pseudotachylite (in the sense of Philpotts, 1964) was found in several localities. The pseudotachylite is restricted to a few of the major movement-zones. These zones form rectilinear depressions which are very distinct on areal photographs and some are inferred to be of regional importance.

The zones strike NE - SW with a dip of about $45^{\circ} \mathrm{NW}$ and their width is about a couple of hundred metres. They are composite systems containing shear zones and crushed rocks s.1. (in most cases recrystallized). The amount of movement is questionable but in a few cases the movement-zones are interpreted as big overthrusts. Other zones show no visible sign of displacement. Generally the movement-zones show a slightly lower degree of metamorphism than the surrounding granulite facies rocks owing to retrogression.

Most pseudotachylite localities were found along an area in the middle of which a diorite was emplaced before granulite facies conditions were reached.

The intrusive character of the pseudotachylite is clearly seen, with cross-cutting veinlets, vermicular bands and very distinctive stringers. These are found along the borders of the movement-zones and in a few cases in the middle of the zones. The maximum width of the veins observed is about $5 \mathrm{~cm}$ and the length up to several metres. At a single locality two generations were seen.

Under the microscope the fluidal structures in the pseudotachylite glass are very distinct together with spherulitic areas with radiating plagioclase microliths. Along the border zones of the glassy types a small rim of ultra-crushed material with weak flow-lines was observed. Inclusions of quartz with strain traces were often seen. The minerals of the gneiss surrounding the pseudotachylite veins have to some extent been microbrecciated and show traces of strain; the general alteration is due to weathering. 
Ultra-crushed material was found also in veins. In the field it was impossible to distinguish these from pure pseudotachylite veins.

Field and microscopic evidence has shown that the formation of pseudotachylite was very late in the development of the area.

Before the discovery of pseudotachylite and ultra-crushed rocks along some of the prominent features in the area it was not known what these features reflect. Now it is clear that intense crushing has taken place along these features, even if the lack of good marker horizons makes it difficult to assess the amount of movement in the zones.

\section{Reference}

Philpotts, A.R. (1964) Origin of pseudotachylites. Amer. J. Sci., Vol. 262, $1008-1035$.

\section{QUATERNARY DEPOSITS AROUND HOLSTEINSBORG}

\section{Anker Weidick}

The area investigated in 1967 is situated between $66^{\circ} 20^{\prime}$ and $67^{\circ} 10^{\prime} \mathrm{N}, 52^{\circ} 30^{\prime}$ and $54^{\circ} \mathrm{W}$, and is part of the high outer coastal terrain of central West Greenland. The greatest heights - more than $1000 \mathrm{~m}$ - are seen in the northernmost and southernmost parts of the area. These parts are separated by an E-W-running depression around Ikertoq fjord, the western continuation of which is seen offshore in Holsteinsborg Dyb (the Holsteinsborg trough), a submarine canyon $500 \mathrm{~m}$ deep separating Store Hellefiske Banke from Lille Hellefiske Banke. Whilst the banks are thought to be ice margin deposits which accumulated during the ice ages, the Holsteinsborg trough acted during these times as a drainage channel for the Inland Ice. 